JOURNAL

of Health Inequalities

\title{
Memories of Stefania Jabłońska
}

\author{
Witold A. Zatoński \\ Health Promotion Foundation, Nadarzyn, Poland \\ Higher Vocational State School in Kalisz, Poland
}

\begin{abstract}
ADDRESS FOR CORRESPONDENCE: Witold A. Zatoński, Health Promotion Foundation, 51 Mszczonowska Street 05-830 Nadarzyn, Poland, e-mail: wazatonski@promocjazdrowia.pl
\end{abstract}

Professor Stefania Jabłońska, a remarkable doctor, dermatologist, and scientist, passed away on May $8^{\text {th }}$, 2017. Professor Jabłońska was best known for her pioneering research on the viral aetiology of cervical cancer. It is to a large extend thanks to her work, conducted in collaboration with the world's best laboratories, that medicine today possesses a set of tools for the control of cervical cancer, also in Poland. A letter I received on 2 July 2017 from Professor Harald zur Hausen, in which he points out "the remarkable achievements in cervical cancer reduction in Poland", is a testament to Professor Jabłońska's great legacy.

In this issue of Journal of Health Inequalites we invite you to read two contributions paying homage to Professor Stefania Jabłońska's work. The first, written by Professor Harald zur Hausen and Dr. Ethel-Michele de Villiers, Stefania Jabłońska - some personal recollections (p. 13), places Professor Jabłońska’s work in an international context. The second, Remembering Professor Jabłons$k a$ (p. 14), is written by Professor Sławomir Majewski, who collaborated with Professor Jabłońska over the course of several decades.

Despite the progress achieved in cervical cancer control, much is still left to be done to build upon Professor Stefania Jabłońska’s legacy. We explored the problem of the persistently high toll of cervical cancer morbidity and mortality in Eastern Europe in last year's issue of the Journal of Health Inequalities $[1,2]$.

\section{DISCLOSURE}

Author reports no conflict of interest.

\section{References}

1. Wojtyła C, Słabuszewska-Jóźwiak A, Janik-Koncewicz K, Zatoński WA. New challenges for cervical cancer. J Health Inequal 2016; 2: 77-88.

2. Zatoński WA, Pisarska-Krawczyk M, Wojtyła C, Janik-Koncewicz K. Patterns of cervical cancer mortality in young adult women in three countries of the European Union: Finland, Poland and Latvia. J Health InequalI 2016; 2: 95-100.

\section{Stefania Jabłońska}

Stefania Szela Ginsburg-Jabłońska was born in Warsaw on September $7^{\text {th }} 1920$. In the years 1926-1937 she attended the Teachers' Union Secondary School in Warsaw. In 1937 she began her medical studies in Warsaw, and in the years 1938-1939 she undertook further studies in Lviv, then in 1939-1942 in Frunze, where she was awarded a degree with honours. In 1946 she graduated as a specialist in dermatology and venereology from the Skin Pathology Faculty of the Soviet Union's Academy of Sciences in Leningrad. That same year she began working as an assistant in the Dermatology Department of the Medical Academy in Warsaw. In 1949, with a fellowship from the World Health Organisation, she gained further experience as an assistant at the University of Pennsylvania in Philadelphia. In 1950 she defended with honours her Ph.D. thesis entitled "Histological features of skin reactions to tuberculin and Mycobacterium tuberculosis extracts". One year after defending her Ph.D. thesis, she also defended her habilitation thesis with honours. In 1974 she was awarded a full professorship. In the years 1949-1990 she headed the Dermatology Department of the Medical Academy in Warsaw, and until 2006 was its professor retired. In the years 1962-1982 and 1987-1995, she was the president of the Polish Dermatological Society and then became its honorary chairperson. She was an honorary member of several dozen dermatological societies around the world and a member of several other prestigious international scientific societies. In 1985 she won the Robert Koch Award.

Professor Jabłońska was particularly interested in the pathogenesis and diagnosis of systemic sclerosis and diseases of the bladder. However, mention must also be made of Professor Jabłońska's achievements in understanding the mechanism of the influence of the human papillomavirus on the development of tumours. It was a team led by her that was one of the first to observe and 
describe autoinoculation. In patients diagnosed with epithelial papillary dysplasia (Epidermodysplasia verruciformis), in whom material taken from a wart was transferred to an unoccupied surface of their body, development of warts was observed within a few dozen weeks.

In 1983, Professors zur Hausen and Gissmann identified type 16 human papillomavirus in a precancerous tumour of the reproductive system and two years later discovered the genetic material of the virus in cervical cancer cells. In 2008, Professor zur Hausen was awarded the Nobel Prize for the above discovery.

Professor Stefania Jabłońska is the author of many academic textbooks (including Skin Diseases), the promoter of 69 doctoral dissertations and 24 habilitation theses, and the educator of 15 professors. She is one of the most distinguished and most frequently cited Polish scientists.

Prepared by Cezary Wojtyła 